\title{
NOVEL KISAH TRAGIS OEI HUI LAN REPRESENTATION OF LIMITATION OF THE EAST AND DEPENDENCE ON THE WESTERN WORLD
}

\author{
Evi Irawanti Br Saragih \\ eviirawanti96@mail.ugm.ac.id \\ Magister Ilmu Sastra, Fakultas Ilmu Budaya, Universitas Gadjah Mada
}

\begin{abstract}
This study uses novel Kisah Tragis Oei Hui Lan Putri Orang Terkaya di Indonesia as material object and theory of representation and orientalism initiated by Edward Said become object formal. The study tries to answer research problem namely how the form of limitations and dependence shown by the character of Chinese descent as a representation of Eastern Society of the West. The results shows that every character as representatives of Eastern society had shown dependence on the West. Oei Tiong Ham, Oei Hui Lan's Father need the help of Dutch officials and government to run his business. Wellington Koo, Oei Hui Lan's husband depends a lot on the West in politic. It is because there are some opinions that west has tremendous power and advance in technology, military, science that still deeply rooted in Eastern societies today and difficult to avoid so creates dependence which is definition of limited condition.
\end{abstract}

Keywords: East-west, novel, orientalism, representation

\section{INTRODUCTION}

Orientalism comes from two different words Orient and Ism. Orient has meaning as something Eastern, whereas Ism signifies an idea, thought or belief. So, orientalism is known as understanding related to eastern problems. Usually, scientists who study matters related to the East in terms of language, literature, religion, and civilization were from West and they called orientalists.

The misrepresentation of orientalists in interpreting and assessing everything related to the Eastern nation gave rise to polemics and distance between the two. This happens over a long period of time even today. Many of the underlying reasons why such thinking persists are even produced in the public domain. The strength and unity shown by the Eastern nations after the crusades was one of them. The West wants to disrupt this, so various efforts are made including involving policy makers, academics, and missionaries.

In Edward W. Said's book Orientalism, it is written that at first westerners only wanted to know the culture of the Eastern people. But looking at the geographical and available resources such as the world's oil sources in the Eastern region, the West also wants to control and conduct direct occupation. Everything related to the East produced by the West was made without involving the Eastern nation itself. Books, translation texts, literary works, and da'wah are media that the West uses to influence all around the world.

Some orientalists give their views on what and how eastern but in negative connotations, among them is Lane. Lane's thoughts and views emerged around the end of the 19th century. Lane said that orientalism belongs to individuals, namely its inventors and researchers. In his various narratives, Lane argues that eastern nations 
are very static and never keep up with developments. Lane seems to be part of the East but the views he conveys are always based on his perspective as a Westerner. There is also Rudyard Kipling, an orientalist who originated the term white and influenced those with that identity to consider themselves to be central to legitimacy, to suppress.

The orientalist view developed into a dogma, that the West and the East were very different and could not be united. The West considers themselves rational, advanced, superior, while the East is considered a deviant and undeveloped nation. The West regards the East as a selfdefining nation and makes them an object so that it can be scientifically studied. At its peak, the East was regarded as frightening (as the source of the yellow plague) but had to be controlled either by direct security, research, or occupation of the territory.

Novel Kisah Tragis Oei Hui Lan Putri Orang Terkaya di Indonesia that was set during 1889 to 1992 showed how Eastern life in the time of colonialization and surrounded by Westerner. The novel tells the journey of Oei Hui Lan who was born with all the luxuries from his father, Oei Tiong Ham, a richest man in Indonesia even in Southeast Asia and known as the sugar king from Semarang. Oei Hui Lan is the second child of Oei Tiong Ham's lawful wife Goei Bing Nio and has an older sister named Oei Tjong Lan. They live in Semarang and live in a luxurious palace-like, a house with an area of 9.2 hectares and have 40 maids, 50 gardeners along with additional private tutors and famous chefs from China, Malay, and Europe.

This novel is considered appropriate if studied with orientalism approach because the character is told to come from Indonesia of Chinese descent that is directly related to the western world, both in politics, economy, and daily lifestyle. The relationship indirectly shows how the characters in the novel as a representation of eastern society faced all the limitations of the great wars of the 19th century, and its dependence on the western world which was seen as great and advanced. At that time, it was known that the Eastern region fell into the hands of the West in political missions as well as through war. For example, when Arab rulers wanted to break away from Ottoman Turkey it led to western intervention in the Middle East. Ottoman Turks in coalition with Germany and Austria-Hungary lost, so much of their territory fell to allied armies.

Western arrivals to different parts of the Islamic world (Eastern Region) are made possible by the absence of unity among local Muslim rulers. On the other hand, Europe-America's development in the fields of military, technology, and science entered its heyday. This prompted easterners in droves to learn everything about the West, including culture, so that they sent their young people to continental Europe-America. New knowledge and experience that can be about the West brings much admiration; the limitations experienced by the East so far can be resolved by westerners. This encourages them to become increasingly powerful countries in any field.

The study about orientalism using literary works on Chinese descent as eastern representations is quite widely conducted, one of which is titled Pandangan Orientalis terhadap Identitas dan Isu Politik Tokoh Perempuan dalam Putri Cina. This one discusses two issues concerning orientalist views on identity and political issues contained in Sindhunata's novel Putri Cina. This study focuses on Postcolonial studies initiated by Edward Said (1978). The result show that orientalist assessments played by female characters in the novel Putri Cina by Shindunata is represented in its existence in Javanese and Chinese society as a female figure who portrays her identity 
with the image of women physically, behaviorally, psychically, and socially.

The research using novel Kisah Tragis Oei Hui Lan as a material object has not been done much since it was first published in 2010. Nofia Angela in 2019 has conducted research under the title Pandangan Pengarang (Agnes Davonar) dalam Novel Oei Hui Lan: Kajian Sosiologi Sastra. The results showed that Agnes thought that Oei Hui Lan's life story was very inspiring, a woman with a life that looked perfect with all the luxuries but everything was pseudo. Having a father with abundant wealth, a husband with an important position in the Chinese government made her forget to be grateful and became the trigger for other problems in her life.

Another research has been conducted by Selly Julita with titled Hilangnya Eksistensi Perempuan pada Novel Kisah Tragis Oei Hui Lan Putri Orang Terkaya di Indonesia. The results showed that patriarchal culture marginalizes women and judges' men should have a dominant role. Women always live within boundaries, while males can acquire various possibilities in their lives. This culture is constantly nurtured and makes women compressed in many ways, from thought, words, to actions. The novel features the position of women who have always been in the shadow of men, from childhood to adulthood. The position of the female as the second makes her have no existence and always depend on the male.

This study tries to explain how the limitations of Eastern society represented by families of Chinese descent who lived in Indonesia during the colonial period and the great wars of the 19th century, to the dependence of the western world that changed the thinking about taste to their lifestyle. This research uses descriptive qualitative method. The data used comes from novels in the form of narrative monologues and dialogues which are then followed by explanations based on the theory of Orientalism initiated by Edward Said.

To limit the area to be studied so that the purpose of the research was achieved, researchers have formulated several problems, they are: What form of limitations and dependence faced by the characters as a representation of Eastern Society in the 19th century in the novel Kisah Tragis Oei Hui Lan? And What is the form of Eastern society's dependence on the Western world in the 19th century depicted in the novel Kisah Tragis Oei Hui Lan?

Orientalism

Edward W. Said in his book on the year 1978 with title Orientalism concluded that orientalism can mean everything related to the East from a Western point of view. Furthermore, Said held that orientalism was a discourse aimed at shaping the East according to Western views. The East is regarded as a nation that cannot define itself and has always depended on the West.

Some Orientalists gave their views on the East in negative connotations such as Robert Smith who argues that the East is primitive despite many movements towards a more modern direction. Smith made a direct observation to Arabia, rather he went to the Hejaz to obtain the acculturation of various statements past and present without dizzying differences. However, Said criticized Smith's writing stating that the knowledge that Europeans had known about Islam (East) was invalid. Said alluded to that the Islam said by Smith was not the true teachings of Islam, but rather Islam constructed by Smith's view as a Westerner.

Limitations of the East and Dependence on the Western World.

The thinking that continues to be echoed by orientalists is many of them able to influence the people of the Eastern Region. The West is always trying to make the East as its shadow to provide all forms 
of assistance, gifts, and facilities that are able to pamper them. In the end it all confined eastern people in one limited state making them always need the West with all its greatness, to try to be like them.

The limited state of Eastern society in any field encourages the West to provide assistance to the point of dependency. This further strengthens the West's position to colonialism not only on the economic system but its society and culture to form hegemony. Mastery has a great influence on the way Eastern people view life, the values that the west brings are beginning to be considered correct and imitated, even into a daily lifestyle.

Lifestyle develops because there is a need, demands and strengthening, is a behavioristic mahzab that states that a behavior will be repeated if it's bringing satisfaction or pleasure and there is no punishment that accompanies it. Lifestyle according to Kotler (2009) is a person's lifestyle in the world expressed in his activities, interests, and opinions. Lifestyle describes "one's whole self" in interacting with its environment.

Lifestyle in max weber's view (in George Ritzer \& Barry Smart, 2012) means the equality of honorary status characterized by consumption against the same lifestyle symbol. Lifestyle is a pattern or culture of human consumptive that combines individuality, selfexpression, and pseudo self-awareness. Body, fashion, speech, leisure entertainment, food and beverage choices, homes, vehicles and entertainment options are seen as indicators of the individuality of taste. Lifestyles derived from the influence of the environment in which people socialize can also be changed by the influence of the environment that follows the currents of the times.

This study used descriptive qualitative as the research method, and the research divided into two stages. The first stage is the process of collecting data. Researcher read the novel Kisah Tragis
Oei Hui Lan, and highlight important things that are considered as temporary data. After that, categorize the data according to what this research wants to focus on.

After those processes, the next is data analysis. The data that has been mapped or entered in the same category is then analyzed to answer the research problem. The last stage is to draw conclusions from all data analysis results.

This research data divided into two parts, namely primary data and secondary data. The primary data is in the form of monologue narratives or dialogue of the characters as a representation of Eastern society that shows their limitations and dependence on the western world in the 19th century where there were many conflicts and major wars. Furthermore, secondary data research includes theoretical texts, journal articles, and other references, including information on online media related to orientalism and postcolonialism.

\section{FINDINGS AND DISCUSSION}

The analysis below uses novel Kisah Tragis Oei Hui Lan, which is taken as a statement or view of the character as a representation of Eastern society in the 19th century where there was a lot of colonialism, conflict and great war. The events eventually revealed the state of the East, which was limited from the scope of the family to the government. Limitations encourage dependence on anything related to the Western world.

As a family of the richest people in southeast Asia at that time, Oei Tiong Ham socialized with people from the West, especially the Dutch and English who had and would do colonialism in Indonesia, then known as Indie (Hindia Belanda). Admiration for western greatness and progress in the fields of technology, science, and so on influenced Oei Tiong Ham much of their thinking. His tastes and lifestyle began to follow 
The West, and this was passed on to his children

The western lifestyle that this family shows every day can be seen from how they choose, using both personally and collectively everything related to Body, fashion, speech, leisure entertainment, food and beverage choices, homes, vehicles, and entertainment. These are indicators of the individuality of taste. The following monologues and dialogue passages show how Oei Tiong Ham's family has been influenced by western.

"We used to live in China town in the suburbs of Semarang, but then my father built a palace in a European real estate area. We became the only Chinese living in the elite compound. Our house has a typical Italian-style physical look with white tiled floor layers". (Davonar 2010:20)

Through the website dekoruma.com, in 1920 houses with Mediterranean architecture that were heavily influenced by typical European continental styles such as Greece, Italy, and Spain were popular in Indonesia. Oei Tiong Ham's decision to choose a Western-style house was assumed to be a way to lure guests from the area. It also shows that starting from the basics, his family has experienced an interest on the Western world. In the novel explained that Oei Tiong Ham's house is often used as a meeting place with governments and officials from Europe, especially Dutch for talking about business. Upon seeing the house's looks, they praised Oei Tiong Ham as a person with high taste and this is boosted his confidence.

Not only in Semarang, Oei Tiong Ham family also has some houses located in several countries such as England and France. To make their house like western style, they often spend a lot of money to buy accessories and furniture. It happened until their final resting place in their old age. Oei Tiong Ham with his young wife
Lucy Ho, and his two daughters with their husband and children.

In addition to the house, clothing and jewelry are also important to be seen as Western. Oei Tiong Ham's wife was the one most interested in this. For clothes, she never thinking how much money she has spent. While jewelry, she willingly went out of Java Island to get Gold, Diamonds with the best quality.

"Then the waiter would take the item and send the bill to Dad's office. I was thinking if mom wears all the stuff she buys, because our warehouse is full of collectibles. All I know is mom only likes the European clothes she buys when visiting. If the clothes are local, most of them give to his faithful servants at the end of the year or before Eid al-Fitr". (Davonar 2010:27)

We can see that Oei Tiong Ham's wife had the same thoughts as him. Western greatness that continues to be spread through the media of the past is increasingly a value of truth that is finally applied to daily life. The East, which was seen by the West as a static part and never advanced, began to do impersonation. Goei Bing Nio, who had a desire to make herself or her two daughters into European jet sets, equipped themself with the noble style. Clothing and jewelry are the most eye-catching ways.

To add the impression that they have become like jet sets, this family often spends time on vacations to some countries of European - American continental. Although they have to be on boat for a long time, this does not detract their fun and pride. Also, this trip often makes them meet famous and respected people such as Princess Alice from Monaco (known as Grandmother of Prince Rainer).

Once satisfied to be in the UK, we continued our journey to France, Spain and Germany. Lastly, we 
continued our journey to America, New York as a vacation spot before returning to Semarang. (Davonar 2010: 119)

Not only Oei Hui Lan's family, in the novel also described how Indonesian officials represented by Soekarno so admired the things about the West. Through Indonesia's National Geographic page, Soekarno's first visit to the United States in 1956 showed what he thinks of the country. He said that America is not just as a country, or a nation, or a person, but also America as a frame of mind, America as the center of ideas. As a young man, it was known that Soekarno was so in the world of Hollywood entertainment. American-produced films became one of his tastes, and the celebrity cast often amazed Soekarno. Marylin Monroe was one of them. The brief meeting of the two led to many interpretations and became horrendous news for a long time.

When he visited America, local newspapers reported how much he was willing to spend his time just looking at Marylin Monroe's performance with a party in her hotel room. In fact, at that time, the state of his country's economy was in turmoil as it faced a sharp economic recession and a high unemployment rate of almost 40 percent. (Davonar 2010: 287)

The state of Indonesia's economy, which was on the brink of crisis, came to the attention of western media when Soekarno met Marylin Monroe. Not without reason, Soekarno was considered to prefer his lifestyle and tastes rather than the suffering of people who have not been fully independent. Development and improvement of the post-colonial economy has not been evenly distributed, business people, landowners and large capital make the most of this situation. For example, Oei Tiong Ham, he willingly utilizes experts from the West to send his workers who are local youth to study far to the Continent.

At that time the industrial
revolution had not yet reached the
island of Java. But I can't hear it.
He brought in German experts to
advise on the machines needed to
grow and process sugar cane. With
the help of the German consul who
helped him, he also sent young men
to Europe to learn how to run
machines and repair in case of
damage. And it proved his instincts
right. Dad's success is continuous.
(Davonar 2010: 118)
In addition to all his efforts, Oei Tiong Ham is also known to be good at getting along and close to many government officials, especially from Dutch who are so long occupying Indonesia. He became a respected person and honored by all circles. Oei Tiong Ham's wealth is not rarely used to provide facilities such as home, transportation for them to launch their business. He also frequently invited government and officials to their family's big events, such as at the wedding of his first daughter, Oei Tjong Lan. They even hold wedding parties using modern Western customs. The invitees were also open to European authorities who became his business partners. (Davonar 2010:79)

Much of Oei Tiong Ham and his wife's thoughts on Western greatness and progress were passed down to their two daughters. In education, the couple hired a private teacher come from Australia and Europe to teach Hui Lan and her older sister English, Dutch and French. Those private teachers lived in a house set up around their house. Not only became teachers, sometimes they became close friends to Oei Hui Lan, especially a woman named Miss Jones. The family put her in their private Villa and have great respect for her (Davonar 2010: 51).

During her study, Hui Lan showed her interest and fondness for Language and 
Literature, one of the works that caught her attention was a story named The Tatler. The Tatler is an American magazine that presents lifestyle, entertainment, and politics written by Richard Steele. It also features a variety of anecdotal stories full of moral messages. This work influenced Hui Lan's life. While with her father, Hui Lan told a story she read in the magazine about the party she was dreaming of. Her father seemed enthusiastic and promised to realize the dream as long as Hui Lan was able to speak English well.

"One of the stories I love the most is the story of The Tatler, the story that inspired me. The Tatler is a story in which a beautiful woman gets a prince through the dance, then the two get married and become a Happy couple. (Davonar 2010: 51)

The love story of the Prince and Princess that Hui Lan often read in Tatler magazine also inspired her meet with the man who became her first love, Siau Kwan. It's happened when Hui Lan learned to ride a horse, but she mis-tracked and got lost, then Siau Kwan came to give a help. Riding a horse at that time even now is known to be studied only by the elite because the costs need is not a little. In fact, Hui Lan and Siau Kwan are in the same course taught by Mr. Smith to learn horseback riding. Unfortunately, their love story must be end as it is forbidden by Hui Lan's parents who already know that Siau Kwan has got married.

Moving on from that, Hui Lan and her family's dependence on the western world is actually showing the limitations faced. Small things concerning the domestic realm of households, entertainment, and business there is always interference and connection with the West. Such a thing actually continues in the larger realm. Hui Lan, who eventually married Wellington Koo, fell further into Western socialite life especially when her husband became China's ambassador to America, Britain and France.

Wellington Koo, who was born with the real name Ku Wei Chun, then was the only one Chinese to change his name in western style. He was a graduate from Columbia University of the United States who was good at politics, so the Chinese government made him be a diplomat. After marriage, Wellington's career intensified, which led to him and Hui Lan increasingly meeting with authorities from continental Europe- America. It is not uncommon for Hui Lan to be left to work by her husband.

When I was six months pregnant, Wellington was asked by the President of China to visit the United States to lobby the American government so that the process of taking Shantung to China could take place quickly. (Davonar 2010:174)

During world war I in 1917, it was known that the Shantung peninsula (Shandong), which had a vital role as a defense base, became a contest between Japan and China, which had been a longtime enemy. Shantung, which was then controlled by the Germans in coalition with the Japanese, did not want to just give up the territory. At the Paris Peace Conference, China represented by Wellington Koo condemned the German surrender to Japan. This could not be done because Shantung was the birthplace of Kong $\mathrm{Hu} \mathrm{Cu}$, just as Christianity could not let go of Jerusalem. Therefore, Wellington lobbied American officials and governments to help China regain Shantung.

The United States is disbursing military weapons assistance to China. Japan felt America was a threat to him so began to attack the American military base in Hawaii known as Pearl Harbor, the attack sparked American anger and thus declared war on Japan and America was plunged into the 
second world war. (Davonar 2010: 256)

During World War II, America, along with Britain, France, the Soviet Union allied with China, faced Japan with the help of Germany and Italy. The assistance provided by countries from continental Europe - America to countries from the Continent of Asia (East) at that time showed that the East was in a limited state. China, with the help of allies, eventually defeated Japan, which was marked by bomb blasts on Hiroshima and Nagasaki, and the Shantung peninsula returned to Chinese hands. But there is no lasting aid, there is always a political mission behind such actions that inevitably benefits the West's position. To this day the thought that the West has tremendous power because of their advances in technology, military, science, and so on is still firmly entrenched in Eastern society. This is difficult to avoid and gives rise to other forms of dependency. Dependency is the definition of limited circumstances, limitations.

\section{CONCLUSION}

Based on the data analysis, it can be concluded that the characters in the novel Kisah Tragis Oei Hui Lan Putri Orang Terkaya di Indonesia as a representation of Eastern society shows dependence on the Western world. Oei Tiong Ham as the head of the family needs the help of officials and governments from the West, especially the Netherlands to launch their business. He sent his workers who are local youth from Indonesia to Europe and America to learn many things, especially how to run and repair factory machinery. The

ambitious Wife made herself and her two daughters, Oei Hui Lan and Oei Tjong Lan into European jet sets began to dress themselves with jewelry and also western style clothes. Wellington Koo, the husband of Oei Hui Lan relies heavily on the West represented by America,
England, and France in terms of politics. The results of the aid can be seen during the war in East Asia and World War II, where Japan suffered defeat, and the shantung region returned to Chinese hands. This success led Wellington Koo to become a reliable politician until he finally succeeded in becoming ambassador to the President of China even in a short time.

The success achieved by the Eastern Region with the help of European countries- America is increasingly favorable to their position. The view that the West has tremendous power because of their advances in technology, military, science, and so on is still firmly entrenched in Eastern society to this day. This is difficult to avoid and gives rise to other forms of dependency. Dependency is the definition of a limited state.

\section{REFERENCES}

Angela, Nofia. 2019. Pandangan Pengarang (Agnes Davonar) dalam Novel Oei Hui Lan: Kajian Sosiologi Sastra. Jakarta: Fakultas Keguruan Ilmu Pendidikan Universitas Esa Unggul

Apriliawati, Ningrum. 2010. Perkembangan Bisnis Gula Oei Tiong Ham di Jawa 1894- 1924. Depok: Universitas Indonesia.

Ardanareswari, Indira. 2019. Kemesraan Sukarno dengan Hollywood dan Politik Film AS di Indonesia. https://tirto.id/kemesraan-sukarnodengan-hollywood-dan-politik-filmas-di-indonesia-eeuM

Davonar, Agnes. 2010. Kisah Tragis Oei Hui Lan Putri Orang Terkaya di Indonesia. Jakarta: Intibook

Dekoruma, kania. 2018. Mengintip Gaya Arsitektur Tahun 1920an di Rumah Mediterania.https://www.dekoruma.c 
om/artikel/62687/gaya-arsitekturrumah-mediterania

Fattah, Abdul. 2019. Critiques and Appreciation on Orientalism in the Study of Islam. Mataram: Universitas Islam Negeri Mataram.

Ige, Edhie P. 2018. Misteri Istana Warisan Raja Gula Asia di Semarang.

https://www.liputan6.com/regional/r ead/3228353/misteri-istana-warisanraja-gula-asia-di-semarang

Julita, Selly. 2020. Hilangnya Eksistensi Perempuan pada Novel Kisah Tragis Oei Hui Lan Putri Orang Terkaya di Indonesia. Depok: Universitas Indonesia

Khaliesh, Hamdil. 2014. Arsitektur Tradisional Tionghoa: Tinjauan Terhadap Identitas, Karakter Budaya dan Eksistensinya. Kalimantab Barat: Universitas Tanjung Pura.

Ritzer, George dan Barry Smart. 2012. Handbook Teori Sosial. Bandung: Nusa Media

Robson, David. 2017. Bagaimana orang Timur dan Barat berpikir dengan cara yang sangat berbeda. https://www.bbc.com/indonesia/vertfut-39202364

Said, Edward W. 2003. Orientalism. London: Penguin Books.

Sakinah, RM. 2014. Pandangan Orientalis terhadap Identitas dan Isu Politik Tokoh Perempuan dalam Putri Cina. Bandung: Universitas Padjajaran.

Santosa, Iwan. 2018. Jejak-jejak Oei Tiong Ham: Konglomerat Gula dari Semarang.https://interaktif.kompas.i d/baca/pabrik-gula/
Thamrin, Mahandis Yoanata. 2019. Di balik foto langka lawatan pertama Soekarno ke Amerika Serikat 1956. https://nationalgeographic.grid.id/rea d/131749096/di-balik-foto-langkalawatan-pertama-soekarno-keamerika-serikat-1956?page $=$ all

Tour, Wita. 2019. Selangkah Lebih Dekat dengan Chinese Philosopy di Shandong.https://www.witatour.com /news/read/33/selangkah-lebihdekat-dengan-chinese-philosophy-dishandong.

Utama, Rai. 2015. Life Style and Social Class is Reflected in Consumer Behaviour for Services Industries. Bali: Universitas Dhyana Pura Bali.

Widodo, Prihastomo W. 2020. Hari ini dalam Sejarah: China menyatakan Perang terhadap Jerman. https://internasional.kontan.co.id/ne ws/hari-ini-dalam-sejarah-chinamenyatakan-perang-terhadapjerman?page $=2$ 